\title{
Synthesis and Herbicidal Activities of Enantiopure Methiozolins
}

\author{
Jun Ho Nam, ${ }^{\dagger,}$, Ki-Hwan Hwang, ${ }^{\ddagger}$ Suk-Jin Koo,${ }^{\ddagger}$ Chong-Hyeak Kim, ${ }^{\S}$ Chang-Woo Cho, ${ }^{\#}$ and Young Kwan Ko ${ }^{\dagger, *}$ \\ ${ }^{\dagger}$ Biomaterials Research Center, Korea Research Institute of Chemical Technology, Daejeon 305-600, Korea \\ *E-mail:ykko@krict.re.kr \\ ${ }^{\star}$ Moghu Reserch Center, Daejeon 305-333, Korea \\ ${ }^{\S}$ Center for Chemical Analysis, Korea Research Institute of Chemical Technology, Daejeon 305-600, Korea \\ ${ }^{\#}$ Department of Chemistry, Kyungpook National University, Daegu 702-701, Korea \\ Received October 25, 2011, Accepted November 4, 2011
}

Key Words : Methiozolin, Absolute configuration determination, Optical isomer, Herbicidal activity, Grass weeds

It is well known that the worldwide demands for crops and biomass exceed their supply due to the rapid growth of world population, limitation of cultivation areas, global warming, climate change and subsequent lack of water supply. Herbicides for weeds control have played an important role in promoting productivity of crops yields and biomass. ${ }^{1}$ Even though a number of herbicides have been developed for weeds control, more eco-friendly new herbicides having new modes of action are needed because of the environmental safety issues and occurrence of resistant weeds. ${ }^{2,3}$ Recently, a new isoxazoline herbicide methiozolin possessing thiophene ring for the control of grass weeds in turf grass has been commercialized. ${ }^{4,5}$ Methiozolin shows not only excellent herbicidal efficacy toward several grass weeds in turf grass but also favorable toxicological and environmental profiles. Methiozolin has one chiral center in isoxazoline ring. Up to now, methiozolin has been developed as a racemate.

However, it was reported that, in many cases, big differences in biological activities between enantiomers of chiral agrochemicals have been observed. ${ }^{6-8}$ In addition, success stories for the commercialization of chiral agrochemicals such as $(S)$-metolachlor ${ }^{9}$ and mefenoxam ${ }^{10}$ as a single isomer by Syngenta prompted us to investigate herbicidal activities of each enantiomer of methiozolin. In our previous paper, ${ }^{11}$ the absolute stereochemistry of one enantiopure intermediate with posititive value of specific optical rotation, which is the key intermediate for synthesis of optically active methiozolin, was determined by single crystal X-ray diffraction analysis after prep- HPLC separation with chiral stationary phase $[(R, R)$-WHELK-O1 column] using [5methyl-3-(3-methylthiophen-2-yl)-4,5-dihydroisoxazol-5yl]methanol as the racemic mixture. Herein, we want to describe synthesis of enantiopure methiozolins and compare herbicidal activities between optical isomers on some grass weeds under a greenhouse condition.

Key intermediates $(S)-\mathbf{3}$ and $(R)-3$ for enantiopure methiozolins could be obtained by chiral separation of a racemic [5-methyl-3-(3-methylthiophen-2-yl)-4,5-dihydroisoxazol-5yl]methanol 3 employing chiral prep-HPLC separaton. Specific optical rotation of the first eluted intermediate was $+59.96\left(c=1.0, \mathrm{CH}_{2} \mathrm{Cl}_{2}\right)$ and that of the second eluted intermediate was $-59.95\left(c=1.0, \mathrm{CH}_{2} \mathrm{Cl}_{2}\right)$. Absolute configuration of one enantiopure intermediate with positive specific optical rotation was determined to be $S$ by single crystal Xray diffraction analysis. And the other enantiopure intermediate with negative but the same absolute value of specific optical rotation could be assigned to have the $R$ configuration. Enantiopure methiozolins could be synthesized by a coupling reaction of each chiral intermediate $(S)$-3 or $(R)$-3 with 2,6-difluorobenzyl chloride under basic condition as shown in Scheme 1.

Specific optical rotation of one enantiopure methiozolin synthesized from (+)-[5-methyl-3-(3-methylthiophen-2-yl)4,5-dihydroisoxazol-5-yl] methanol $(S)$-3 was $+55.0(c=$ 1.0, $\mathrm{CH}_{2} \mathrm{Cl}_{2}$ ) and that of the other enantiopure methiozolin synthesized from (-)-[5-methyl-3-(3-methylthiophen-2-yl)4,5-dihydroisoxazol-5-yl]methanol $(R)$-3 was $-54.5(c=1.0$, $\mathrm{CH}_{2} \mathrm{Cl}_{2}$ ). Finally, absolute configuration of one enantiopure methiozolin with positive specific optical rotation was deter-

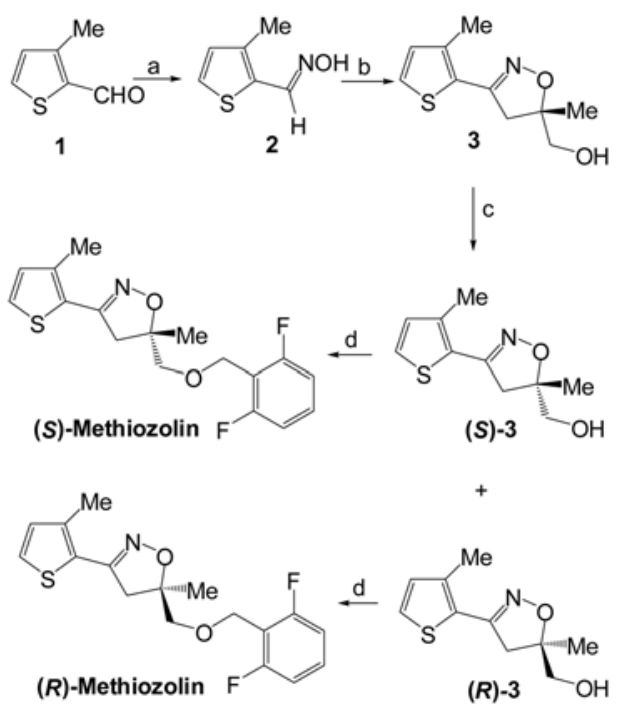

Scheme 1. Synthesis of enantiopure methiozolins.

Reagents and conditions: (a) $\mathrm{H}_{2} \mathrm{NOH} \cdot \mathrm{HCl}, \mathrm{MeOH}$; (b) NCS, $\mathrm{CH}_{2} \mathrm{Cl}_{2}$, 2-methylpropen-1-ol, $\mathrm{NaHCO}_{3}$. (c) chiral prep-HPLC separation. (d) 2,6-difluorobenzyl chloride, $\mathrm{NaOH}$, THF 


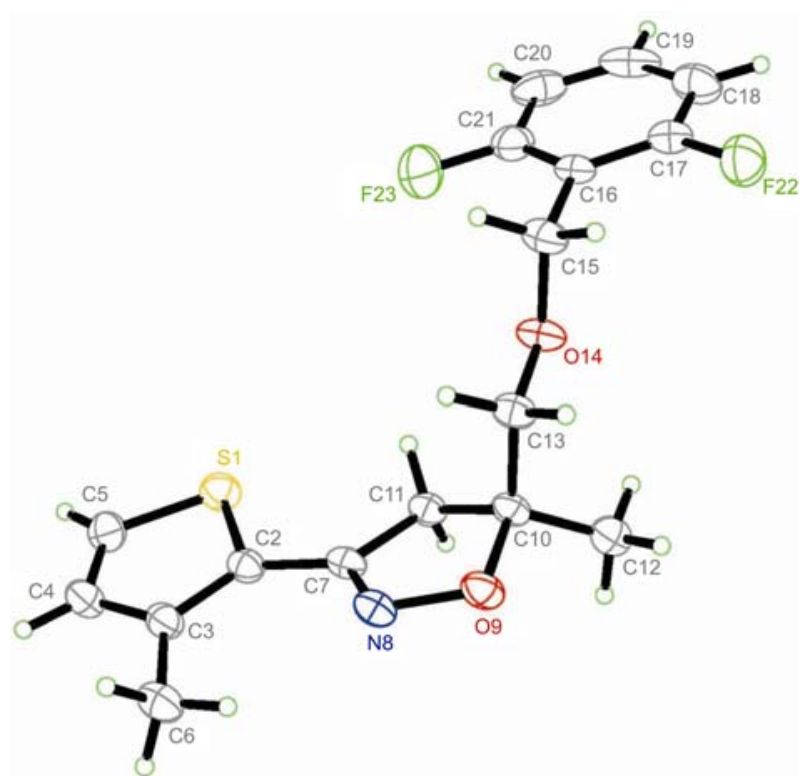

Figure 1. ORTEP drawing of $(S)$-methiozolin.

mined to be the $\mathrm{S}$ configuration by single X-ray diffraction analysis (Figure 1). ${ }^{12}$ In addition, the other enantiopure methiozolin with negative but the same absolute value of specific optical rotation could be assigned to be the $R$ configuration.

Biological Evaluation Pre-emergence herbicidal activities of racemic methiozolin and its enantiopure isomers toward troublesome grass weeds such as Digitaria sanguinalis and Poa annua in turf grass were tested under a greenhouse condition. As shown in Figure 2, herbicidal activities of racemic methiozolin and its optical isomers towards Digitaria sanguinalis and Poa annua were in order of $(S)$-isomer, racemic methiozolin and $(R)$-isomer. Surprisingly, $(R)$-isomer exhibited no herbicidal activities toward grass weeds tested.

In conclusion, each enantiomer of methiozolin was synthesized from the key intermediates $(S)-3$ and $(R)-\mathbf{3}$, respectively, which were prepared by prep-HPLC separation with chiral stationary phase. The absolute configuration of $(S)$ methiozolin was determined by single crystal X-ray diffraction analysis. Interestingly, only $(S)$-isomer of methiozolin showed the herbicidal activities toward grass weeds.

\section{Experimental}

${ }^{1} \mathrm{H}$ NMR (500 MHz) and ${ }^{13} \mathrm{C}$ NMR (75 MHz) spectra were recorded in $\mathrm{CDCl}_{3}$. The signal positions are reported in parts per million relative to TMS ( $\delta$ scale) used as an internal standard. IR spectra are reported in $\mathrm{cm}^{-1}$. Mass spectra, elemental analysis and single crystal X-ray diffraction analysis were carried out at Korea Research Institute of Chemical Technology, Daejeon, Korea. All reagents were purchased from commercial sources and used without further treatment. Flash chromatography was carried out using silica gel 60 (230-400 mesh ASTM) using various solvent mixtures.

Chiral separation was performed on a YOUNGLIN SDV30plus series HPLC system (YOUNGLIN, Seoul, South Korea). The injection volume was $20 \mu \mathrm{L}$. The following HPLC columns purchased from $(R, R)$ WHELKO1 of REGIS Chemical Industries (USA) were used: The Whelk-O 1 Chiral Stationary Phase is based on 1-(3,5Dinitro benzamido)-1,2,3,4-tetra-hydrophenanthrene.

3-Methyl-2-thiophenecarboxaldoxime (2). Freshly distilled 3-methyl- 2-thiophenecarboxaldehyde (126.0 g, 1.0 $\mathrm{mol})$ was dissolved in methanol/water solution $(200 \mathrm{~mL} / 150$ $\mathrm{mL})$, and hydroxylamine hydrochloride $(76.5 \mathrm{~g}, 1.1 \mathrm{~mol})$ was added during $15 \mathrm{~min}$ at $10-15{ }^{\circ} \mathrm{C}$ with good stirring. A solution of $\mathrm{NaOH}(44.0 \mathrm{~g}, 1.1 \mathrm{~mol})$ in water $(50 \mathrm{~mL})$ was added dropwise to the reaction mixture, and it was stirred for an additional $15 \mathrm{~min}$ at room temperature. The reaction mixture was concentrated by rotary evaporation to precipitate white crystalline solids. The precipitates were filtered and dried under vacuum to afford 3-methyl-2-thiophenecarboxaldoxime (139.0 g, 98.5\%) mp 111.0-112.0 ${ }^{\circ} \mathrm{C} ;{ }^{1} \mathrm{H}$ NMR $\left(500 \mathrm{MHz}, \mathrm{CDCl}_{3}\right) \delta 2.44(\mathrm{~s}, 3 \mathrm{H}), 6.95(\mathrm{~d}, J=5.1 \mathrm{~Hz}$, 1H), 7.49 (d, $J=5.1 \mathrm{~Hz}, 1 \mathrm{H}), 7.81(\mathrm{~s}, 1 \mathrm{H})$; C NMR $(75$

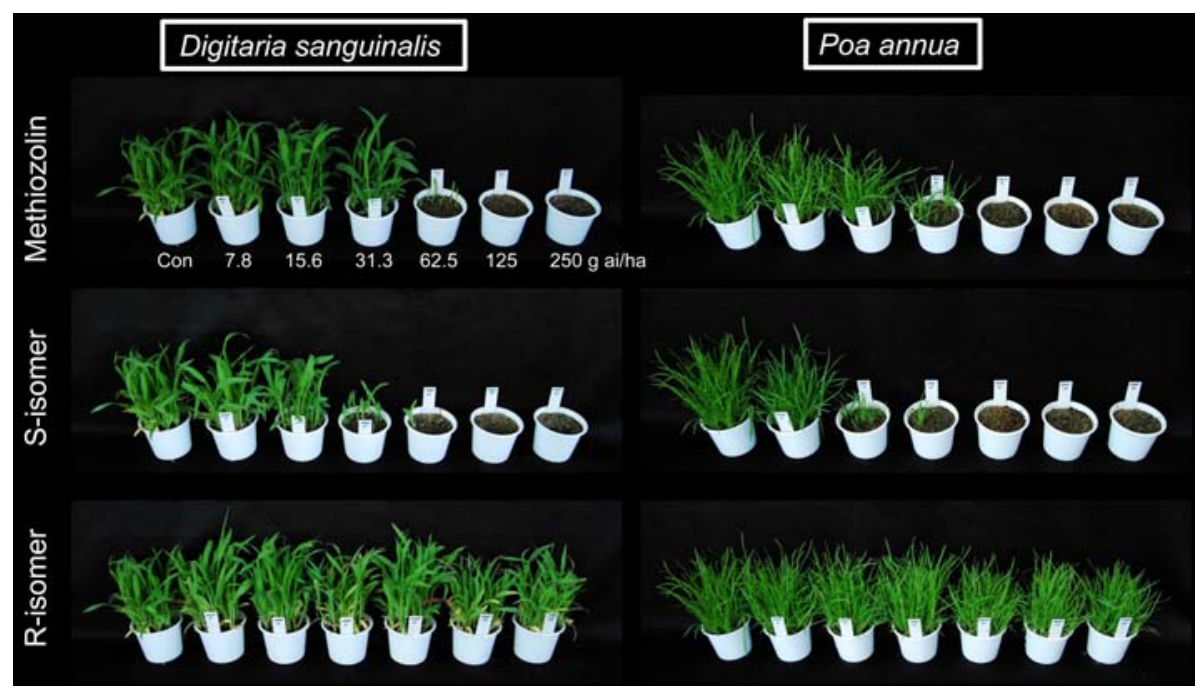

Figure 2. Herbicidal activities of racemic methiozolin and enantiopure isomers toward Digitaria sanguinalis and Poa annua. 
$\left.\mathrm{MHz}, \mathrm{CDCl}_{3}\right) \delta 14.5124 .9129 .2130 .4139 .6141 .1$.

[5-Methyl-3-(3-methyl-thiophen-2-yl)-4,5-dihydroisoxazol-5-yl]methanol (3). To a solution of 3-methyl-2thiophenecarboxaldoxime (2) (139.0 g, $0.98 \mathrm{~mol})$ in $\mathrm{CH}_{2} \mathrm{Cl}_{2}$ $(1000 \mathrm{~mL})$ was added $\mathrm{N}$-chloro succinimde (152.2 g, 1.14 $\mathrm{mol}$ ) by potions for $45 \mathrm{~min}$ at $10-40{ }^{\circ} \mathrm{C}$. After the reaction mixture was stirred for an additional $3 \mathrm{~h}$, it was poured into methylene chloride $(1000 \mathrm{~mL})$. The solution was washed with water $(200 \mathrm{~mL} \times 2)$ and brine $(300 \mathrm{~mL} \times 2)$, dried over $\mathrm{MgSO}_{4}$, and filtered. The filtrate was placed in a 2-L round bottomed flask, and 2-methylpropen-1-ol (86.6 g, $1.2 \mathrm{~mol}$ ) and sodium bicarbonate $(108.0 \mathrm{~g}, 1.2 \mathrm{~mol})$ were slowly added to the mixture for $30 \mathrm{~min}$ at $5{ }^{\circ} \mathrm{C}$. The reaction mixture was stirred for $12 \mathrm{hr}$ at room temperature, washed with brine $(200 \mathrm{~mL} \times 2)$. The organic layer was dried over $\mathrm{MgSO}_{4}$, and concentrated by rotary evaporation to give a pale yellow solid. A total of $50 \mathrm{~mL}$ of ethyl acetate and 250 $\mathrm{mL}$ of hexane were added to the solid with good shaking, and then, the suspension was cooled in an ice bath. The solid precipitates were filtered and washed with hexane to give [5Methyl-3-(3-methyl-thiophen-2-yl-4,5-dihydroisoxazol-5yl]methanol (3) as a racemic mixture $(186.0 \mathrm{~g}, 90 \%) \mathrm{mp}$ 94.9-97.7 ${ }^{\circ} \mathrm{C}$; ${ }^{1} \mathrm{H}$ NMR $\left(500 \mathrm{MHz}, \mathrm{CDCl}_{3}\right) \delta 1.44(\mathrm{~s}, 3 \mathrm{H})$, $2.24(\mathrm{~s}, 3 \mathrm{H}), 3.06(\mathrm{~d}, J=16.35 \mathrm{~Hz}, 1 \mathrm{H}), 3.53(\mathrm{~d}, J=16.4 \mathrm{~Hz}$, $1 \mathrm{H}), 3.59$ (d, $J=11.9 \mathrm{~Hz}, 1 \mathrm{H}), 3.76(\mathrm{~d}, J=12.0 \mathrm{~Hz}, 1 \mathrm{H})$, 6.93 (d, $J=5.0 \mathrm{~Hz}, 1 \mathrm{H}), 7.29$ (d, $J=4.2 \mathrm{~Hz}, 1 \mathrm{H})$; C NMR $\left(75 \mathrm{MHz}, \mathrm{CDCl}_{3}\right) \delta 16.522 .644 .667 .2 \quad 86.9126 .1126 .3$ 132.0139 .0153 .1 .

Chiral Separation of [5-Methyl-3-(3-methyl-thiophen2-yl)4,5-dihydroisoxazol-5-yl]methanol (3). Racemic [5Methyl-3-(3-methyl-thiophen-2-yl)-4,5-dihydroisoxazol-5yl]methanol was separated by preparative chiral HPLC under the condition of $(R, R)$ WHELK-O1 column, hexane/ isopropylalcohol $7.5 / 2.5 \mathrm{v} / \mathrm{v}$ mobile phase, flow-rate 4.0 $\mathrm{mL} / \mathrm{min}, k \neq 254 \mathrm{~nm}, 100 \mu \mathrm{L}$ injection volume to give the first eluted isomer $(\boldsymbol{S})-\mathbf{3}$ and the second eluted isomer $(\boldsymbol{R})-\mathbf{3}$. $[\alpha]_{\mathrm{D}}^{20}$ of the first eluted isomer $(\boldsymbol{S})-\mathbf{3}=+59.96(c=1.0$, $\left.\mathrm{CH}_{2} \mathrm{Cl}_{2}\right) ;[\alpha]_{\mathrm{D}}^{20}$ of the second eluted isomer $(\boldsymbol{R})-3=-59.95$ $\left(c=1.0, \mathrm{CH}_{2} \mathrm{Cl}_{2}\right.$ ). The first eluted isomer was recrystallized in ethyl acetate to provide the single crystal for X-ray crystallograph.

(S)-5-(2,6-Difluorobenzyloxymethyl)-5-methyl-3-(3-methylthiophen-2-yl)-4,5-dihydroisoxazole. To a solution of (S)-[5-methyl-3-(3-methyl-thiophen-2-yl)-4,5-dihydroisoxazol-5-yl]methanol $(\boldsymbol{S})-3(105.5 \mathrm{~g}, 0.5 \mathrm{~mol})$ in THF (400 $\mathrm{mL})$ was added $\mathrm{NaOH}(66.6 \mathrm{~g}, 1.1 \mathrm{~mol})$ during $15 \mathrm{~min}$ at 40 ${ }^{\circ} \mathrm{C}$, and the mixture was stirred for $15 \mathrm{~min}$ at that temperature. A solution of 2,6-difluorobenzyl chloride (97.6 g, 0.6 $\mathrm{mol})$ in THF $(60 \mathrm{~mL})$ was added to the reaction mixture during $15 \mathrm{~min}$, and the reaction temperature increased to 60 $70{ }^{\circ} \mathrm{C}$. The reaction mixture was stirred for an additional $1 \mathrm{~h}$ at that temperature and poured into ice water $(500 \mathrm{~mL})$. The solution was extracted with ethyl acetate $(500 \mathrm{~mL} \times 2)$, and the organic layer was washed with $1 \mathrm{~N} \mathrm{HCl}$ solution $(200 \mathrm{~mL}$ $\times 2)$ and brine $(200 \mathrm{~mL} \times 2)$. The organic layer was dried over $\mathrm{MgSO}_{4}$ and concentrated to give crude product, which was purified by silica gel column chromatography (300 g,
1:20 ethyl acetate/hexane) to provide pure product as oil. The oily product was recrystallized in hexane to give $(S)-5-$ (2,6-difluorobenzyl)oxymethyl-5-methyl-3-(3-methylthiophen-2-yl)-1,2-isoxazoline as a white crystalline solid (100.0 g, 60\%). mp 45-46 ${ }^{\circ} \mathrm{C} .{ }^{1} \mathrm{H}$ NMR (500 MHz, $\left.\mathrm{CDCl}_{3}\right) \delta 1.47$ (s, 3H), $2.46(\mathrm{~s}, 3 \mathrm{H}), 3.02(\mathrm{~d}, J=16.45 \mathrm{~Hz}, 1 \mathrm{H}), 3.45$ (d, $J=$ $16.50 \mathrm{~Hz}, 1 \mathrm{H}), 3.54$ (d, $J=9.9 \mathrm{~Hz}, 1 \mathrm{H}), 3.60(\mathrm{~d}, J=9.85 \mathrm{~Hz}$, 1H), 4.72 (s, 2H), 6.93-6.89 (m, 3H), 7.31-7.26 (m, 2H); MS $\mathrm{m} / z$ (relative intensity): 338 (17.8), 337 (42.5), 180 (87.3), 137 (100), 127 (53.6); IR (KBr, cm $\left.{ }^{-1}\right): 3104.0,2973.2,2928.2$, 2882.7, 1626.8, 1471.0, 1234.7, 1097.5, 1056.6, 786.0; Anal. Calcd for $\mathrm{C}_{17} \mathrm{H}_{17} \mathrm{~F}_{2} \mathrm{NO}_{2} \mathrm{~S}: \mathrm{C}, 60.52 ; \mathrm{H}, 5.08 ; \mathrm{N}, 4.15$; S, 9.50. Found: C, 60.53; H, 5.20; N, 4.14; S, 9.43; UV $\lambda_{\max }$ : $279.5 \mathrm{~cm}^{-1} ;[\alpha]_{\mathrm{D}}^{20}=+55.50\left(c=1.0, \mathrm{CH}_{2} \mathrm{Cl}_{2}\right)$.

(R)-5-(2,6-Difluorobenzyloxymethyl)-5-methyl-3-(3-methylthiophen-2-yl)-4,5-dihydroisoxazole. To a solution of (R)-[5-methyl-3-(3-methyl-thiophen-2-yl)-4,5-dihydroisoxazol-5-yl]methanol $(\boldsymbol{R})-3(105.5 \mathrm{~g}, 0.5 \mathrm{~mol})$ in THF (400 $\mathrm{mL})$ was added $\mathrm{NaOH}(66.6 \mathrm{~g}, 1.1 \mathrm{~mol})$ during $15 \mathrm{~min}$ at 40 ${ }^{\circ} \mathrm{C}$, and the mixture was stirred for $15 \mathrm{~min}$ at that temperature. A solution of 2,6-difluorobenzyl chloride (97.6 g, 0.6 $\mathrm{mol})$ in $\mathrm{THF}(60 \mathrm{~mL})$ was added to the reaction mixture during $15 \mathrm{~min}$, and the reaction temperature increased to 60$70{ }^{\circ} \mathrm{C}$. The reaction mixture was stirred for an additional $1 \mathrm{~h}$ at that temperature and poured into ice water $(500 \mathrm{~mL})$. The solution was extracted with ethyl acetate $(500 \mathrm{~mL} \times 2)$, and the organic layer was washed with $1 \mathrm{~N} \mathrm{HCl}$ solution $(200$ $\mathrm{mL} \times 2)$ and brine $(200 \mathrm{~mL} \times 2)$. The organic layer was dried over $\mathrm{MgSO}_{4}$ and concentrated to give crude product, which was purified by silica gel column chromatography (300 g, 1:20 ethyl acetate/hexane) to provide pure product as oil. The oily product was recrystallized in hexane to give (R)-5-(2,6-difluorobenzyl)oxymethyl-5-methyl-3-(3-methylthiophen-2-yl)-1,2-isoxazoline as a white crystalline solid (100.0 g, 60\%). mp 45-46 ${ }^{\circ} \mathrm{C} .{ }^{1} \mathrm{H}$ NMR $\left(500 \mathrm{MHz}, \mathrm{CDCl}_{3}\right) \delta$ 1.47 (s, 3H), 2.46 (s, 3H), 3.02 (d, $J=16.45 \mathrm{~Hz}, 1 \mathrm{H}), 3.45$ $(\mathrm{d}, J=16.50 \mathrm{~Hz}, 1 \mathrm{H}), 3.54(\mathrm{~d}, J=9.9 \mathrm{~Hz}, 1 \mathrm{H}), 3.60(\mathrm{~d}, J=$ 9.85 Hz, 1H), 4.72 (s, 2H), 6.93-6.89 (m, 3H), 7.31-7.26 (m, $2 \mathrm{H})$; MS $m / z$ (relative intensity): 338 (17.8), 337 (42.5), 180 (87.3), 137 (100), 127 (53.6); IR (KBr, cm $\left.{ }^{-1}\right)$ : 3104.0, 2973.2, 2928.2, 2882.7, 1626.8, 1471.0, 1234.7, 1097.5, 1056.6, 786.0; Anal. Calcd for $\mathrm{C}_{17} \mathrm{H}_{17} \mathrm{~F}_{2} \mathrm{NO}_{2} \mathrm{~S}: \mathrm{C}, 60.52 ; \mathrm{H}, 5.08 ; \mathrm{N}$, 4.15; S, 9.50. Found: C, 60.53; H, 5.20; N, 4.14; S, 9.43; UV $\lambda_{\max }: 279.5 \mathrm{~cm}^{-1} ;[\alpha]_{\mathrm{D}}^{20}=-54.50\left(c=1.0, \mathrm{CH}_{2} \mathrm{Cl}_{2}\right)$.

Acknowledgments. This work was supported by the R\&D Program of MKE/KEIT [10035240, Development of new herbicides for resistant weeds with mutated gene].

\section{References}

1. Pimentel, D.; Pimentel, M. Food, Energy and Society, Arnold, E., London, CRC press: 1979.

2. Boger, P.; Wakabayashi, K.; Hirai, K. Herbicide Classes in Development (mode of acton, targets, genetic engineering, chemistry), Berlin, Heidelberg: Springer-Verlag: 2002.

3. Bryant, R.; Bite, M. Ag Chem New Compound Review, United Kingdom, Agranov: 2011. 
4. Hwang, I. Y.; Kim, H. R.; Jeon, D. J.; Hong, K. S.; Song, J. H.: Cho, K. Y. J. Agric. Food Chem. 2005, 53, 8639.

5. Koo, S.-J.; Hwang, K.-H.; Jeon, M.-S.; Kim, S.-H.; Lim, J.-S.; Lee, D.-K.; Chung, K.-H.; Ko, Y. K.; Ryu, J. W.; Koo, D. W.; Woo, J. C. Kor. J. Weed Science 2010, 30, 323.

6. Williams, A. Pestic. Sci. 1996, 46, 3.

7. Kurihara, N.; Miyamoto, J.; Paulson, G. D.; Zeeh, B.; Skidmore, M. W.; Hollingworth, R. M.; Kuiper, H. A. Pure and Appl. Chem. 1997, 69, 2007

8. Williams, A. Phytoparasitica 2000, 28, 293.

9. Moser, H.; Rihs, G.; Sauter, H. P.; Bohner, B. Pesticide Chemistry: Human Welfare and the Environment, Vol. 1, Pergamon, New York: 1982.
10. Sukul, P.; Spiteller, M. Reviews of Environmental Contamination and Toxicology 2000, 164, 1.

11. Ko, Y. K.; Ryu, J. W.; Koo, D. W.; Woo, J. C.; Kim, C.-H. Acta Cryst. 2011, E67, o1040.

12. Crystal data of $(S)$-methiozolin compound: solvent of crystal growth (hexane-diethyl ether); empirical formular $\mathrm{C}_{17} \mathrm{H}_{17} \mathrm{NO}_{2} \mathrm{~F}_{2} \mathrm{~S}$, $F w=337.38$, crystal dimensions $0.40 \mathrm{~mm} \times 0.19 \mathrm{~mm} \times 0.08 \mathrm{~mm}$, monoclinic, space group $P 2_{1}, a=10.449$ (1) $\AA, b=5.1485(7) \AA, c$ $=30.622(5) \AA, \alpha=90^{\circ}, \beta=96.936(9)^{\circ}, \gamma=90^{\circ}, V=1635.3(4) \AA^{3}$, $Z=4, D_{\text {calcd }}=1.370 \mathrm{~g} / \mathrm{cm}^{3}, F_{000}=704, \operatorname{MoK} \alpha(\lambda=0.71073 \AA), R_{1}$ $=0.0495, w R_{2}=0.1047(I>2 \sigma(I))$. The X-ray data has been deposited in CCDC with number 848038 . 